\title{
Effects of extreme floods on the Daphnia ephippial egg bank in a long narrow reservoir
}

\author{
Ivana VANÍČKOVÁ ${ }^{1,2) *}$, Jaromir SED'A ${ }^{2)}$, Jiří MACHÁČEK ${ }^{2)} \&$ Adam PETRUSEK $^{3)}$ \\ ${ }^{1)}$ University of South Bohemia, Faculty of Science, Department of Ecosystem Biology, Branišovská 31, 37005 České Budějovice, \\ Czech Republic \\ ${ }^{2)}$ Biology Centre of the Academy of Sciences of the Czech Republic, Institute of Hydrobiology, Na Sádkách 7, 37005 České \\ Budějovice, Czech Republic \\ ${ }^{3)}$ Charles University in Prague, Faculty of Science, Department of Ecology, Viničná 7, 12844 Prague 2, Czech Republic \\ *e-mail corresponding author: ivana.vanickova@gmail.com
}

\section{ABSTRACT}

Ephippial egg banks are important reservoirs of dormant stages that allow the recovery of Daphnia populations after unfavourable periods. Although the contribution of hatchlings from ephippia to a population in the water column is probably of minor importance in permanent water bodies with a year-round Daphnia persistence, this may differ after major disturbances. In 2006, two 500-year floods hit the long and narrow Vranov Reservoir (Czech Republic), in which we had investigated zooplankton densities and ephippia distribution in the sediment in preceding years. In this study, we evaluated the impact of those extraordinary floods on the population of the Daphnia longispina complex, and particularly on the local dormant egg bank. We considered two alternative hypotheses related to the egg bank: that either the substantial input of new material with the flood completely buried and therefore reset the existing egg bank, or that the sediment including ephippia was redistributed in the reservoir after the flood and dormant eggs could be exposed to hatching stimuli. A year after the floods, we did not observe any sediment layer that would be devoid of ephippia. However, we observed a significant increase in the proportion of empty ephippia and a decrease in the proportion of those containing eggs. We attribute these changes to disturbance of the sediment due to the floods, which caused redistribution of ephippia stored in the sediment and those detached from the reservoir shoreline. Dormant eggs inside ephippia deposited to shallow parts of reservoir after the floods could therefore receive and respond to hatching stimuli. Hatching from ephippia may have contributed to Daphnia recovery after the spring flood; however, a significant proportion of the Daphnia population probably survived the summer flood protected in the epilimnetic refuge of the thermally stratified environment.

Key words: resting eggs, ephippium, flood, canyon-shaped reservoir, Daphnia longispina complex

\section{INTRODUCTION}

Many aquatic invertebrates, including cladocerans such as planktonic Daphnia species have the ability to undergo diapause (Fryer 1996). Dormancy in Daphnia occurs in the embryonic stage in the form of resistant dormant eggs stored in a special protective case called the ephippium (Zaffagnini 1987). Typically, there are up to $10^{3}-10^{6}$ ephippia stored in the surface layers of every square meter of sediments in lakes and ponds (Brendock \& De Meester 2003).

The ability to diapause, in fact a migration in time, provides daphnids a means to disperse into new regions or habitats, including intercontinental dispersal (see Adamowicz et al. 2009), and to bridge periods of unsuitable conditions (Hairston 1996); this ensures the persistence of a population in its habitat. Thus, the role of recruitment from ephippia is crucial for populations in habitats that do not sustain Daphnia year-round (Edmondson 1955; Hotový \& Petrusek 2007; Lindholm \& Hessen 2007)

The relevance of sexually produced resting eggs for Daphnia population dynamics and genetic structure is less clear in permanent water bodies (Cáceres \& Tessier 2004). In lakes and reservoirs with long-term persistence of Daphnia populations in the water column, novel hatchlings from ephippia have to compete with adapted genotypes that have successfully passed through the period of clonal erosion and are already present in the water column (De Meester et al. 2002; Vanoverbeke \& De Meester 2010). In deep lakes, another major obstacle to successful ephippial recruitment into the population of the water column is the limited access of hatching cues, such as light and temperature, to the resting eggs (Schwarz \& Hebert 1987). Therefore, ephippia in the sediment of deeper lake parts might be considered more as a sink, and the dormant egg bank as an archive of genotypes rather than a source of regular increment to the population. However, those ephippia that are deposited in shallow parts are more likely to hatch regularly, and there is some evidence that ephippia may contribute to population dynamics also in deep permanent habitats (Cáceres 1998; Rossi et al. 1998; Rother et al. 2010). A study on a Central European reservoir reported depth-dependent hatching rates, with a higher hatching rate in shallower depths (Rother et al. 2010). 
Ephippia stored in the lake bottom are continuously buried deeper by sediment settling. In the natural conditions of shallow lakes, they may return to surface sediment layers with access of hatching cues through several mechanisms that redistribute the sediment, particularly bioturbation by fish (Ritvo et al. 2004; Matsuzaki et al. 2007) and benthic macroinvertebrates (Kearns et al. 1996), or by the impact of turbulent storms (Kerfoot et al. 2004). In deep lakes and reservoirs with steep slopes, these mechanisms probably play a much smaller role.

Man-made reservoirs, built by damming rivers in steep valleys, are a special case of anthropogenic lakelike habitats. Their specific hydrologic characteristics and morphology, with a considerable longitudinal depth gradient, result in a large variation of environmental conditions along the main reservoir axis (Straškraba 1998), affecting most trophic levels. Although most canyon-shaped reservoirs in Central Europe have a relatively short retention time, their pelagic communities show spatial gradients in composition of all important functional groups of biota (e.g., bacteria: Šimek et al. 2008; heterotrophic protists: Jezbera et al. 2003; phytoplankton: Hejzlar \& Vyhnálek 1998; zooplankton: Seda \& Devetter 2000; Seda et al. 2007b; fish: Vašek et al. 2004; Prchalová et al. 2008). Environmental gradients also result in the non-random distribution of coexisting Daphnia species (Petrusek et al. 2008a), suggesting relatively stable selection principles shaping Daphnia communities in the water column.

Reservoirs and their inhabitants are nevertheless still influenced by variation in river in- and outflow. Minor floods occur frequently, usually in spring, and the local communities recover well from their impact. However, reservoirs are subjected to major floods with unpredictable frequency, which must have profound impacts on planktonic communities. The timing as well as the magnitude of a flood is crucial, and the impact on the lake or reservoir biota differs according to the particular taxon, its size, and mobility (e.g., for fish see: Kubečka et al. 2004; Čech et al. 2007; for zooplankton: Seda \& Macháček 1998; Rellstab et al. 2007; for phytoplankton: Znachor et al. 2008; Rychtecký \& Znachor 2011). Although Richardson (1992) experimentally showed that daphnids exhibit negative rheotaxis, they were not able to resist flow velocities over $3 \mathrm{~cm} \mathrm{~s}^{-1}$. As Daphnia do not show any tendency to avoid flows by clinging to substrates or rapid swimming (Richardson 1992), they are more likely to be washed out than benthic or littoral species. Some studies have reported the effects of major floods on pelagic zooplankton populations (Zurek \& Dumnicka 1989; Seda \& Macháček 1998; Paidere et al. 2007), but to our knowledge, only one considered the consequences of flood events on the dormant egg bank in a permanent deep lake (Rellstab et al. 2007).

In this study, we took advantage of a unique event in which the Vranov reservoir (southeast Czech Republic) was affected by two major 500-year floods within a sin- gle year. As these floods hit a previously studied site, we were able to evaluate the impact of such a disturbance on the local dormant egg bank. We analyzed the patterns of ephippia distribution in the reservoir and the state of resting eggs in the ephippia, comparing the situations before the floods and one to three years after the floods. We assessed the possible importance of hatching to the re-establishment of the Daphnia population by evaluating evidence for two alternative scenarios with contrasting impacts on the dormant egg bank: 1) newly imported allochtonous material overlays the existing sediment (which may or may not be eroded by the flow), therefore effectively blocking the dormant egg bank from contributing to the recovery of the Daphnia population; 2) sediment is resuspended by the flood and the ephippia within are redistributed throughout the reservoir. Consequently, dormant eggs (including those previously buried in the sediment) may be exposed to hatching cues after the flood. In the former case, recovery of the Daphnia population would rely mainly on individuals surviving in the reservoir or imported from the watershed; in the latter, Daphnia could emerge from ephippia and re-establish the populations from locally produced genotypes.

\section{METHODS}

\subsection{Studied locality and species}

Palaearctic lake habitats, including reservoirs in Central Europe, are usually inhabited by members of the Daphnia longispina species complex (mainly $D$. galeata, D. longispina and D. cucullata, Brandl et al. 1989; for nomenclatural issues, see Petrusek et al. 2008b). All three of these species have been simultaneously found in the studied reservoir (Seda et al. 2007b; Petrusek et al. 2008a), and presence of their ephippial eggs in the local sediment was genetically confirmed (Vaníčková et al. 2010). Reliable morphological traits to identify ephippia from different taxa of the $D$. longispina complex are not yet available; nor could they successfully be distinguished by size in habitats where the species coexist (I. Vaníčková, unpublished data). Furthermore, ephippia carrying hybrids were found in this reservoir (Vaníčková et al. 2010). Therefore, in this study we did not differentiate between Daphnia taxa and evaluated the effect of the floods on the whole resting egg bank.

The studied Vranov Reservoir (Czech Republic; $48^{\circ} 54^{\prime} \mathrm{N}, 15^{\circ} 49^{\prime} \mathrm{E}, 352 \mathrm{~m}$ a.s.l.), constructed in the Dyje (Thaya) river valley in 1939, is relatively large and deep (length $18 \mathrm{~km}$, area $7.7 \mathrm{~km}^{2}$, maximal depth $45 \mathrm{~m}$ ). The sedimentation rate of a reservoir with similar character-

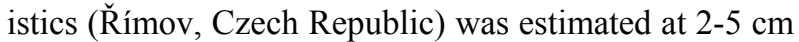
per year in the upstream part and 1-2 cm near the dam (Hejzlar et al. 2008), suggesting that even recently produced ephippia are relatively quickly covered by sediment.

More information about the Vranov Reservoir and particularly about the composition of its Daphnia 


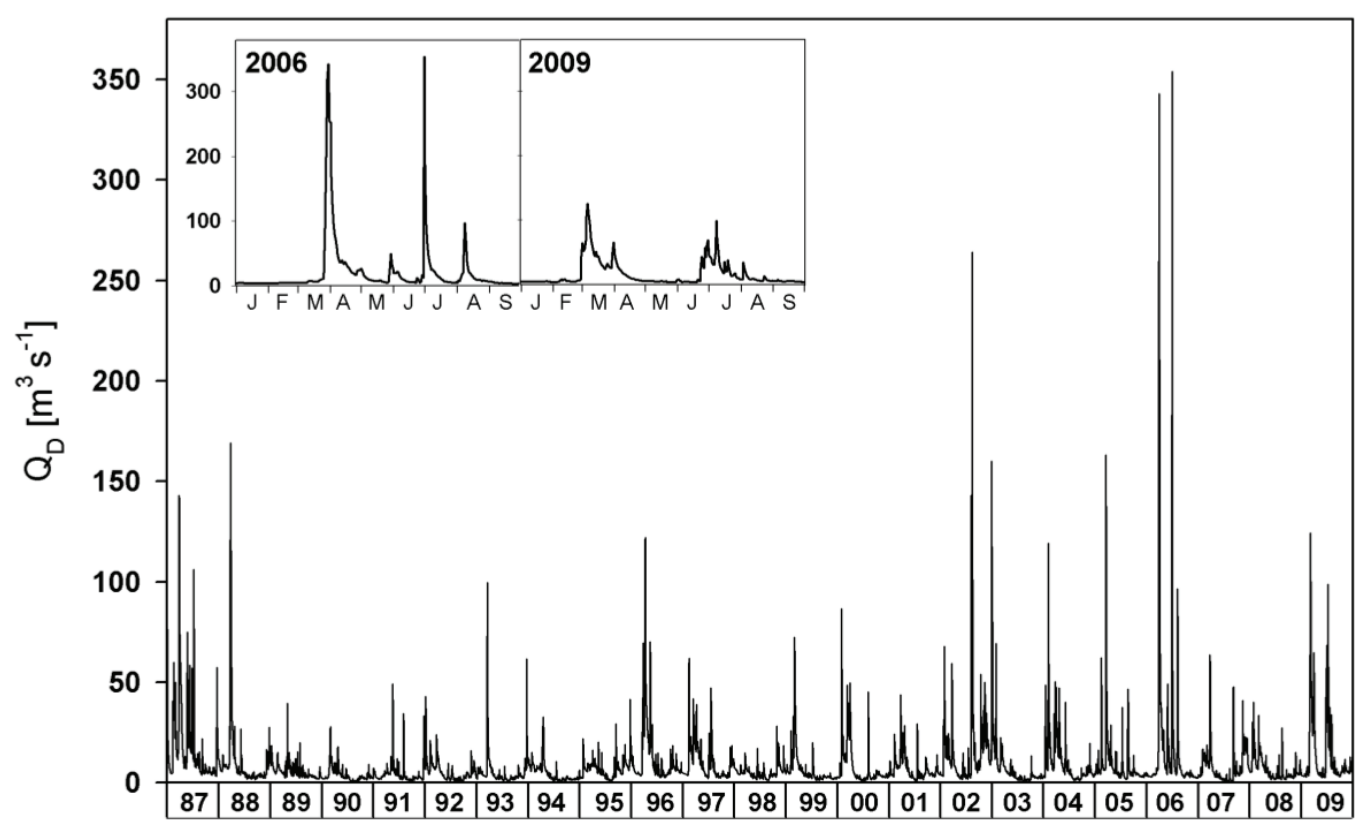

Fig. 1. Average daily inflow $\left(Q_{D}\right)$ to the Vranov Reservoir between January 1987 and December 2009. Details of the years 2006 and 2009 (January to September) are shown in the inset. Data were provided by the Czech Hydrometeorological Institute, Department of Hydrology, Brno, Czech Republic.

populations is given in Seda et al. (2007b) and Petrusek et al. (2008a, includes a map with sampling sites). Vaníčková et al. (2010) also provided a comparison of the local ephippial egg bank with several similar reservoirs in the Czech Republic.

\subsection{The floods}

The Vranov Reservoir has one main tributary, the Dyje River, with a long-term average daily inflow into the reservoir of $9.74 \mathrm{~m}^{3} \mathrm{~s}^{-1}$. In 2006, this value was twice exceeded by two orders of magnitude (Fig. 1). On March 30 , the daily average culminated at $343 \mathrm{~m}^{3} \mathrm{~s}^{-1}$, and this was surpassed only three months later, with the daily average on June 29 reaching $354 \mathrm{~m}^{3} \mathrm{~s}^{-1}$. However, the first flood was more massive in volume: the whole reservoir volume was renewed within five days, plus twice more during three subsequent weeks of high inflow. The second flood was brief in comparison: the high level of inflow lasted for only several days, and replaced in total approximately two thirds of the reservoir volume within a week. In 2009, two smaller floods affected the reservoir, with similar timing but substantially lower magnitude in comparison to 2006 (Fig. 1). On March 6, 2009, the flood pulse peaked at $124 \mathrm{~m}^{3} \mathrm{~s}^{-1}$; this spring flood exchanged $60 \%$ of reservoir water within one week. On July 8 , the inflow reached $99 \mathrm{~m}^{3} \mathrm{~s}^{-1}$ and the flood renewed one third of the reservoir volume within one week.

\subsection{Sampling and sample processing}

We followed the sampling pattern of zooplankton and sediment from our previous studies (Seda et al. 2007b; Petrusek et al. 2008a; Vaníčková et al. 2010).
Sampling took place at three sites along the longitudinal axis of the Vranov Reservoir: upstream (with depth $c a$ $4 \mathrm{~m})$, middle ( $c a 20 \mathrm{~m})$ and at the dam (ca $40 \mathrm{~m})$.

The sediment for analysis of ephippial banks was sampled at two upstream sites within $1 \mathrm{~km}$ of each other, to reduce variation caused by 1) water level fluctuation potentially affecting sediment distribution, and 2) relatively low densities of ephippia in the uppermost sampling site. Results of egg bank analyses from these two upstream sites were pooled together.

Reference data from the period before the floods were obtained from cores collected in 2004 (upstream and dam regions) and 2005 (upstream only), and presented in Vaníčková et al. (2010). Possible changes of the egg banks due to the floods was then studied by comparing pre-flood data (pooled for the upstream region) to those from cores collected from all three sampling stations in 2007, 2008 and 2009. The coring always took place in summer; the sampling dates and the number of collected cores are given in table 1 .

Tab. 1. List of sediment cores collected in the Vranov Reservoir in 2004-2009. Total numbers of ephippia found in the sediment and examined for egg quality are given. In 2006 , it was not possible to sample the sediment, as access to the reservoir was restricted for safety reasons.

\begin{tabular}{ccc}
\hline Sampling date & Sediment cores & N ephippia \\
\hline 19 Jul 2004 & 2 upstream, 2 dam & 305 \\
25 Jul 2005 & 2 upstream & 64 \\
31 Jul 2007 & 4 upstream, 2 middle, 2 dam & 1062 \\
24 Jul 2008 & 4 upstream, 2 middle, 2 dam & 1368 \\
22 Jul 2009 & 6 upstream, 2 middle, 2 dam & 3595 \\
\hline
\end{tabular}




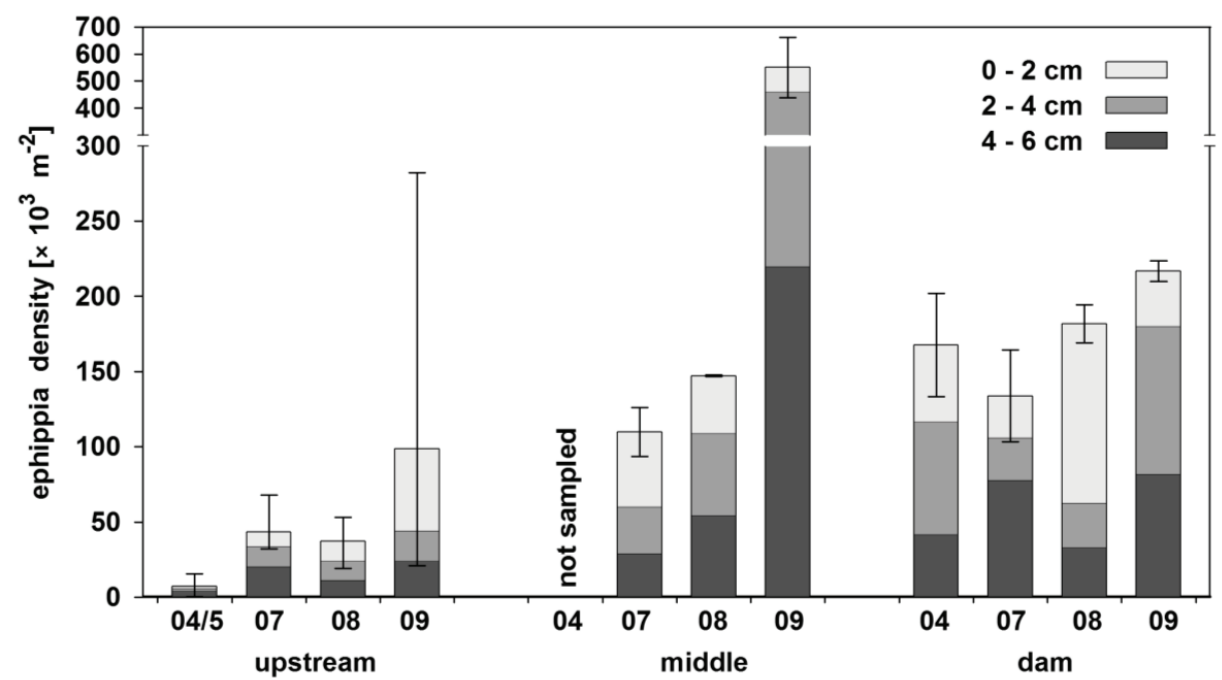

Fig. 2. Abundance of ephippia in the upper $6 \mathrm{~cm}$ of sediment along the longitudinal axis of Vranov Reservoir in the period 2004-2009. Sum of the average density per site (columns) and range of minimal and maximal values (bars) are indicated. The middle site had not been sampled before the floods. Densities from 2004-2005 are taken from Vaníčková et al. (2010).

All sediment cores were taken from the deepest part of the respective sampling site by a gravitational corer with an inner diameter of $5 \mathrm{~cm}$ (sampled area $19.6 \mathrm{~cm}^{2}$ ). The top $6 \mathrm{~cm}$ layer from each core was cut for further processing into three $2 \mathrm{~cm}$ layers, though data obtained from these layers were pooled for subsequent analyses. The sediment was stored in the dark at $5{ }^{\circ} \mathrm{C}$.

The sediment was processed following the protocol described in Vaníčková et al. (2010). All isolated Daphnia ephippial capsules were opened to check for the presence of ephippial eggs and to determine their number and quality. We distinguished three categories (after Vaníčková et al. 2010): a well-preserved egg (labelled as Y), an aborted egg (i.e., with clearly altered shape, colour, fungal infection, etc.; labelled A), and the absence of an egg $(\mathrm{N})$. As each ephippium may contain two eggs, in total six combinations of egg state within an ephippium were possible. We analyzed the whole ephippia content rather than status of individual eggs. Apart from demonstrating the synchronous fate of sibling eggs (which occurred in at least $72 \%$ of ephippia examined per site in five Czech reservoirs; Vaníčková et al. 2010), this allows other factors to be evaluated, such as the proportion of ephippia containing at least some viable eggs (i.e., dormant genotypes) or the proportion of completely empty ephippia (which result from various processes: production of empty ephippia, successful hatching, and egg degradation).

Daphnia from the water column were sampled at all three sampling stations every year from 2004 to 2009 (see Tab. 2 for sampling dates). In 2004-2005 and 20072009 , zooplankton was collected at the same time as the sediment cores (i.e., in summer). In 2006, zooplankton samples were taken twice after the first flood and once after the second. In 2009, an extra sample after the first flood was taken. Daphnia were collected by vertical hauls of $175 \mu \mathrm{m}$ mesh size Apstein plankton nets through the whole water column, and preserved in a formalin solution to estimate abundance.

\subsection{Data analysis}

Original ephippia counts were recalculated per unit area. To summarize ephippia abundances and egg quality (Figs 2 and 3), data were pooled from all cores taken at each site. However, for statistical evaluations of dormant egg abundances, we used data from individual cores separately. For both the upstream and dam region, we compared the densities of ephippia before the 2006 floods with those in 2007, using the Mann-Whitney U test. Due to small sample sizes, the provided p-values are exact probabilities calculated as $p=2 \times(1-P)$, where $P$ is the cumulative one-sided probability of the respective $U$ statistics. At the dam site, we further evaluated among-year variation by the nonparametric KruskalWallis one-way analysis of variance, with year identity as a grouping variable and ephippia density as a dependent variable.

The changes in frequencies of egg quality were assessed using Chi-square tests for goodness of fit of post-flood (2007) data to the original pre-flood distribution (i.e., 2004-5). We compared changes in all categories, and then separately for ephippia with fully preserved eggs (YY) and empty (NN) between 2004 and 2007 or 2009 , respectively.

\section{RESULTS}

\subsection{Distribution of ephippia in the sediment}

Despite the 2006 floods, ephippia were abundantly found at all sampled sites in 2007, and in all sampled sediment layers from the surface down to $6 \mathrm{~cm}$ (Fig. 2). We did not find any layer of allochtonous material 


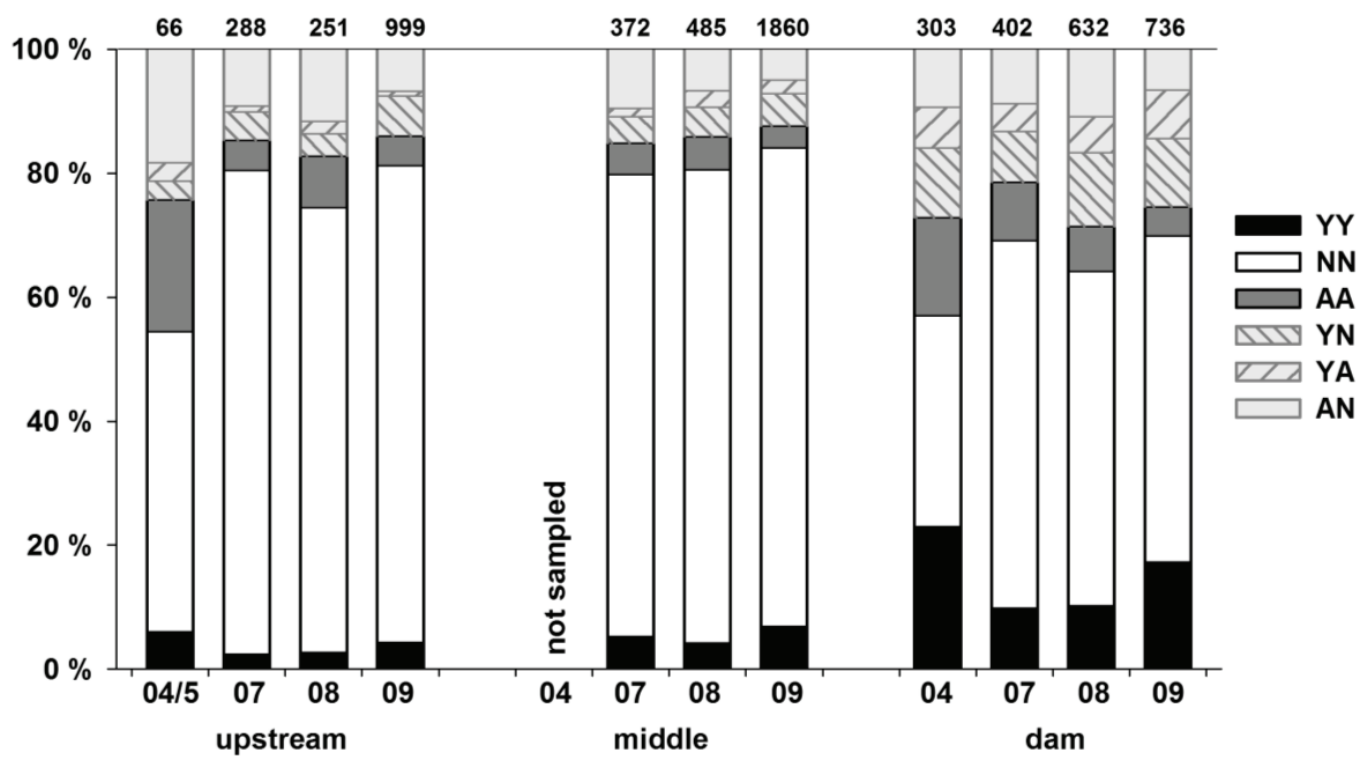

Fig. 3. Annual changes in the preservation of eggs in ephippia along the longitudinal axis of Vranov reservoir in the period 2004-2009. The following categories were distinguished: well-preserved egg (labelled as Y), aborted egg (A), and absent egg (N). The total number of examined ephippia is indicated above the bars. Data from 2004-2005 are taken from Vaníčková et al. (2010).

devoid of ephippia. The general pattern of ephippia distribution in the sediment observed before the flood was maintained in subsequent years: the density of ephippia increased in the downstream direction and the highest abundances were usually found near the dam, with the exception of 2009 (Fig. 2). The highest variability among cores was observed in the upstream region, where observed densities in cores collected within a particular year varied by two orders of magnitude.

In the upstream part of the reservoir, ephippia densities significantly increased after the floods (from 6.6 to $43.2 \times 10^{3}$ ephippia $\mathrm{m}^{-2}$; Mann Whitney $\mathrm{U}$ test: exact $p=$ 0.028 ). In 2009 , we observed unusually high ephippia densities in the sediment, particularly in the upstream and middle sampling sites (Fig. 2). The densities recorded in 2009 in the middle of the reservoir (on average $5.5 \times 10^{5}$ ephippia $\mathrm{m}^{-2}$ ) exceeded those from the dam site more than twice, and were the highest ever recorded in cores from the Vranov Reservoir.

At the dam region, we found a lower number of ephippia stored in the sediment in 2007 than in 2004; however, this trend was not significant (Mann Whitney $\mathrm{U}$ test: exact $p=0.67$ ). In all studied years, ephippia densities at the dam site showed relatively low, insignificant, year-to-year variability (Kruskal-Wallis ANOVA: $\mathrm{H}=5.17, p=0.16$ ). The density values calculated from individual cores remained in the range between 1.0 and $2.2 \times 10^{5}$ ephippia $\mathrm{m}^{-2}$ (average $1.8 \times 10^{5}$ ephippia $\mathrm{m}^{-2}$, Fig. 2).

\subsection{Quality of resting eggs}

The preservation of eggs within each ephippial capsule was evaluated in all 6394 ephippia found during the study (2004-2009). The floods resulted in significant changes in the relative proportions of the 6 categories (Fig. 3; Chi-square test 2004 vs 2007 for the upstream and dam, $\chi^{2}=39.53$ and $\chi^{2}=34.58$ respectively, $p<10^{-3}$ for both tests). One year after the flood, we noticed a significant decrease in the proportion of ephippia containing well-preserved eggs in both upstream and dam regions (Chi-square test 2004 vs 2007: $\chi^{2}=36.83, p$ $\left.<10^{-3}\right)$. These proportions dropped to less than half of those recorded before the flood (from $6 \%$ to $2 \%$ upstream, and from $23 \%$ to $10 \%$ at the dam); this decrease was not accompanied by an increase in the proportion of aborted eggs. Instead, we found a nearly two times higher proportion of empty ephippia in both upstream and dam sites (increasing from $48 \%$ to $78 \%$, and from $34 \%$ to $59 \%$, respectively; Chi-square test 2004 vs 2007: $\left.\chi^{2}=9.66, p=0.001\right)$. In the following years, we observed a slow increase in the proportion of ephippia with well-preserved eggs at all sampled sites along the reservoir longitudinal axis, practically reaching the original pre-flood values in 2009 (Chi-square 2004 us 2009 for YY: $\chi^{2}=1.87, p=0.17$ ). Despite the increase in the proportion of full ephippia, however, we did not observe a corresponding decrease in empty ones, which remained significantly more frequent than before the floods (Chi-square, 2004 vs 2009 for $\mathrm{NN}: \chi^{2}=$ 26.48, $p<10^{-3}$ ). Nevertheless, a slight decreasing trend in the proportion of empty ephippia was observed in 2008, but slowed in 2009 .

\subsection{Daphnia in water column}

Summer abundances of Daphnia in the water column showed high among-year variation at all sampling sites (Tab. 2). Similarly as in the resting eggs bank, the highest variation was observed in the upstream part of 
Tab. 2. Abundance of adult Daphnia of the D. longispina complex in the water column (in thousands per $\mathrm{m}^{2}$ ) in the Vranov Reservoir during the studied years. Depth at the middle and dam sampling stations varied according to the water level in the reservoir. Apart from sampling dates, flood peaks with the highest inflows into the reservoir are indicated.

\begin{tabular}{|c|c|c|c|c|c|c|c|c|c|c|c|c|c|}
\hline \multirow[t]{2}{*}{ Site (depth) } & \multirow{2}{*}{$\begin{array}{c}2004 \\
19 \mathrm{Jul}\end{array}$} & \multirow{2}{*}{$\begin{array}{c}2005 \\
25 \mathrm{Jul}\end{array}$} & \multicolumn{5}{|c|}{2006} & \multirow{2}{*}{$\begin{array}{c}2007 \\
31 \mathrm{Jul}\end{array}$} & \multirow{2}{*}{$\begin{array}{c}2008 \\
24 \mathrm{Jul}\end{array}$} & \multicolumn{4}{|c|}{2009} \\
\hline & & & $31 \mathrm{Mar}$ & 6 May & 7 Jun & 29 Jun & $14 \mathrm{Jul}$ & & & 6 Mar & 7 May & $8 \mathrm{Jul}$ & $22 \mathrm{Jul}$ \\
\hline Upstream (4 m) & 25 & 44 & \multirow{3}{*}{$\begin{array}{l}\vec{D} \\
\stackrel{0}{I} \\
\frac{0}{I}\end{array}$} & 0.2 & 2.4 & \multirow{3}{*}{$\begin{array}{l}\text { N } \\
\stackrel{8}{0} \\
\frac{0}{1}\end{array}$} & 166 & 301 & 693 & \multirow{3}{*}{$\begin{array}{l}\vec{Z} \\
\overline{0} \\
\bar{I}\end{array}$} & 16 & \multirow{3}{*}{$\begin{array}{l}N \\
\overrightarrow{8} \\
\frac{0}{I}\end{array}$} & 222 \\
\hline Middle (ca $20 \mathrm{~m}$ ) & 206 & 1018 & & 1.0 & 35 & & 564 & 250 & 703 & & 82 & & 532 \\
\hline $\operatorname{Dam}(c a 40 \mathrm{~m})$ & 81 & 513 & & 38 & 643 & & 562 & 203 & 252 & & 1500 & & 564 \\
\hline
\end{tabular}

the reservoir, where the summer densities of Daphnia ranged within two orders of magnitude. After the spring flood of 2006, the abundances were low at all sampling sites. In early June, the usual Daphnia summer abundance had already been reached at the dam station but the population abundance was still low at the inflow and middle station (Tab. 2). Even though the reservoir was affected by the second major flood in late June, Daphnia abundances were comparable to previous years two weeks after this event. Moreover, the values in the upstream site were substantially higher than those from summers 2004 and 2005. In the following years, high Daphnia densities in the upstream region (in comparison with pre-floods values) remained, with a particularly high peak in 2008 (Tab. 2). In 2009, when the reservoir was hit by two floods of similar timing as in 2006 (but with lower inflow, Fig. 1), Daphnia densities in both May and July reached relatively high values at all sampled sites (Tab. 2).

\section{DISCUSSION}

Despite two extraordinary floods, the previously observed pattern of ephippia distribution in the sediment, i.e., an increase in the downstream direction, was maintained. However, changes in ephippia density and quality were seen when focusing on the patterns at particular sampling sites. The increase of ephippia abundances in the upper part of the reservoir in 2007 raised the question of their origin, as such an amount of ephippia could not have come from any upstream water body. Since many of the ephippial capsules found had damaged edges, we assume that a substantial proportion of those ephippia were of pre-flood local origin. We suppose that the considerable amount of ephippia in the top sediment layers could be due to two mechanisms: firstly, as a result of the release of ephippia previously attached to the shoreline while floating; secondly, from redistributed reservoir sediments due to turbulent flood inflows.

A striking feature in the temporal trend of ephippia densities was an exceptional peak in cores collected in 2009 from the middle part of the reservoir. We presume that this was a consequence of the unusually high Daphnia densities in the upstream region in 2008, which exceeded those recorded in the two preceding years $(2006,2007)$ by two to four times (Tab. 2). The ephippia produced by such an abundant population were likely partly deposited locally (their densities also increased in the inflow region in 2009, though not as markedly as in the middle) and partly flushed downstream. However, they were unlikely to be washed from the upstream region along the whole reservoir length, as suggested by genetic analyses of the egg banks sampled from both upstream and downstream Vranov sites in 2004 (Vaníčková et al. 2010). This is supported by the distribution of ephippia in 2009, as we did not observe a notable increase of ephippia abundance at the dam site.

Although the Daphnia population in the water column reached high abundance soon after the second flood, it is reasonable to assume that the population had suffered due to the magnitude of the floods in 2006. The impact of such floods on a population in the water column depends on a number of factors. In off-season periods, such as early spring or late autumn, a flood might have stronger impact on a population, because the growth rate of the population is low and cannot compensate for losses due to washout (Rellstab et al. 2007). In a similar type of reservoir, the size of the overwintering community is normally at least two orders of magnitude lower in comparison to summer, and Daphnia undergo a seasonal bottleneck after ice-melt (Seda 1989). During the 500-year flood at the end of March, which in total flushed the whole reservoir volume twice, a substantial part of the population may have been lost for two reasons. First, the water column was not thermally stratified, and the flood pulse therefore influenced the whole reservoir volume. Second, the floodwater was discharged not only through the regular subsurface outflow but also over the spillway for at least six days (data from the State Water Authority). Within this short period, the amount of flood water flowing through the reservoir was equal to its whole volume.

The impact of the 2006 summer flood on the Daphnia population in Vranov was most likely mitigated by one of the principal differences between most deep reservoirs and natural lakes, the location of the outlet (Straškraba 1998). Unlike in lakes, the outlet in many reservoirs (including Vranov) is located in deeper strata, well below the thermocline and often close to the bottom. Under normal conditions, the water level does not reach the spillway and no surface (epilimnetic) water is released. In the Vranov Reservoir, during the 2006 summer flood and both 2009 floods, the outflow volume 
was discharged only through this subsurface outlet, therefore releasing hypolimnetic water. As the inflow temperature after heavy rains is generally lower than the epilimnion temperature in a thermally stratified water column, summer floods have generally less impact on Daphnia populations than spring ones, as reservoir Daphnia reside mostly in the epilimnion during summer and do not perform diel vertical migration (Seda et al. 2007a, b). Usually, Daphnia in downstream parts of the reservoirs are relatively little affected by floods; Seda $\&$ Macháček (1998) reported almost no effect on the total densities of zooplankton in the downstream part of the elongated Rímov Reservoir, even though the same flood severely affected zooplankton in the upstream part. Even if water flows over the spillway, epilimnetic Daphnia may not be strongly influenced, since floodwaters flow through the reservoir in deeper layers and resurface only close to the dam.

Another important parameter that affects the impact of floods on Daphnia populations is the trophic status of the particular water body, which may influence recovery through growth rates. In an oligotrophic lake, the flood effect can be apparent even after several weeks (Rellstab et al. 2007). However, we assume that the strength of the flood impact on planktonic communities depends even more on the type and morphology of the respective water body (lake $v s$ reservoir, wide $v s$ elongated), and, apparently, on the flood timing and extent of water column stratification.

A flood may not have only negative impacts on pelagic zooplankton populations. One positive effect may be in the substantial input of nutrients, which enables fast phytoplankton growth after the flood (Znachor et al. 2008). Such an increase in food supply may facilitate the recovery of Daphnia as well as other pelagic filter feeders. However, high Daphnia abundances shortly after the summer floods of 2006 and 2009 in the Vranov Reservoir (Tab. 2) were more likely due to the survival of significant parts of the population in unaffected surface water refuges and upstream migration (similarly as reported by Seda \& Macháček 1998), rather than fast growth, as Daphnia carried only small clutches of eggs in summer 2006 (J. Seda, unpublished).

Floods also bring a large amount of suspended particles from the watershed, and at least part subsequently settles in the reservoir. Although we did not measure the exact sedimentation rates in this particular reservoir, a major flood of similar extent as the ones in this study deposited a 5-cm thick layer of sediment to the Římov reservoir, and higher sedimentation rates remained for the next several years (Hejzlar et al. 2008). However, our data clearly show that despite the two 500-year floods, the dormant Daphnia egg bank in Vranov was not removed or overlain with allochtonous sediment (Fig. 2). The sudden strong inflow could have caused turbulences resulting in the mixing of the top surface layers of the sediment. Ephippia contained within may have been transported and deposited after the flood to shallower parts of the reservoir bottom, where they could have been exposed to hatching cues. Indeed, the presence of some full ephippia in all analysed layers of the cores a year after the flood suggests that sufficient ephippia were available for hatching after the flood. Furthermore, due to sediment redistribution this major disturbance might have facilitated the activation of Daphnia genotypes stored in the ephippial egg bank, which would otherwise have remained buried.

Apart from the redistribution of ephippia stored in the sediment, the significant changes found in the proportion of empty ephippia after the floods could have resulted from several processes, such as intensive hatching, differences in the sedimentation rates of empty and full ephippia resuspended by turbulent currents, or deposition of ephippia produced empty due to lack of fertilization. The production of empty ephippia is common in natural populations, and may occur in relatively high frequencies (Cáceres 1998; Conde-Porcuna et al. 2011). Although we do not have data about sexual activity and fertilization success in Daphnia inhabiting the reservoir before or after the floods, and these processes may have been influenced by such major disturbances, we do not expect that changes in sexual reproduction (and thus the proportion of emptyreleased ephippia) would be maintained over three seasons. Therefore, we conclude that the significant decrease of well-preserved eggs resulted from increased hatching in the reservoir, and that the floods acted as triggers.

Direct proofs of Daphnia hatching in deep permanent water bodies with a permanent population, such as in-situ measurements of ephippial recruitment in the sediment, are rarely reported, mainly due to methodological difficulties (Cáceres 1998; Rother et al. 2010). In the Vranov Reservoir, indirect evidence of recruitment may be seen in the rapid increase of Daphnia abundance in the water column in late spring (Tab. 2). If hatching occurred and neonates contributed to the Daphnia community in the water column, the subsequent success of hatchlings might have been facilitated by other flood impacts. Flood pulses have the highest impact on adult Daphnia carrying eggs (Richardson 1992). Therefore, while food conditions for Daphnia are rich, competition between new hatchlings from ephippia and well-established and abundant clones in the water column due to resource monopolization (De Meester $e t$ al. 2002) is likely to be lowered, as is predation pressure by planktivorous fish fry (Čech et al. 2007).

It is tempting to suggest that the conspicuous postflood increase of Daphnia and ephippial abundances in the upstream and middle region is also an indirect consequence of the floods. This might have been the case in 2006 and 2009; however, the mechanism behind the increase in 2007-2008 is not clear. There is no indica- 
tion that the trophic status or food supply at the inflow region increased, and it is highly unlikely that predation pressure by fish would have been substantially lower. Although floods may have some short-term consequences for the fish community in reservoirs such as the redistribution of fish fry (Čech et al. 2007), adult planktivorous fish seem not to be affected (Kubečka et al. 2004; Ŕíha et al. 2009). We cannot rule out that the flood altered some of the spawning substrates for fish; however, a significant drop in young-of-the-year fish predation on Daphnia in years following the flood is not likely.

\section{CONCLUSIONS}

We observed a rapid increase of Daphnia abundance in the water column after both 500-year floods. While a considerable proportion of the Daphnia population seems to have survived in the reservoir during the summer flood, it is likely that most of the daphnids from the water column were flushed out in spring. Although disturbed by the floods, the sediment contained ephippia in the surface layers; dormant eggs within could therefore receive hatching cues, especially if redistributed. Our results confirm that Daphnia populations in reservoirs can survive even large floods in the stratified water column; however, the contribution of individuals hatching from ephippial eggs to the rapid recovery of the Daphnia community after such major disturbance events might also be important.

\section{ACKNOWLEDGEMENTS}

Various parts of this study were funded by the Czech Science Foundation (project no. 206/04/0190), the Grant Agency of the Academy of Sciences of the Czech Republic (IAA600960901), the Academy of Sciences of the Czech Republic (projects 1QS600170504 and AVOZ60170517), and the Czech Ministry of Education (MSM0021620828). I. Vaníčková was also supported by the Grant Agency of the University of South Bohemia (projects 034/2008/P and 142/2010/P). We highly appreciate the support of the State Water Authority during the sampling. We thank Š. Dlouhá and V. Nuc for assistance during the sampling, and the Czech Hydrometeorological Institute, Department of Hydrology in Brno and the State Water Authority, Department of Morava River, The Dyje River Branch, Vranov n. Dyjí for hydrological data. Christian Rellstab and Carla E. Cáceres provided helpful reviews that improved a previous version of the manuscript.

\section{REFERENCES}

Adamowicz, S.J., A. Petrusek, J.K. Colbourne, P.D.N. Hebert \& J.D.S. Witt. 2009. The scale of divergence: A phylogenetic appraisal of intercontinental allopatric speciation in a passively dispersed freshwater zooplankton genus. Mol. Phylogenet. Evol., 50: 423-436.

Brandl, Z., B. Desortová, J. Hrbáček, J. Komárková, V. Vyhnálek, J. Seda \& M. Straškraba. 1989. Seasonal changes of zooplankton and phytoplankton and their mutual relations in some Czechoslovak reservoirs. Arch. Hydrobiol. Beih. Ergebn. Limnol., 33: 597-604.

Brendonck, L. \& L. De Meester. 2003. Egg banks in freshwater zooplankton: evolutionary and ecological archives in the sediment. Hydrobiologia, 491: 65-84.

Cáceres, C.E. 1998. Interspecific variation in the abundance, production, and emergence of Daphnia diapausing eggs. Ecology, 79: 1699-1710.

Cáceres, C.E. \& A.J. Tessier. 2004. To sink or swim: Variable diapause strategies among Daphnia species. Limnol. Oceanogr., 49: 1333-1340.

Čech, M., J. Kubečka, J. Frouzová, V. Draštík, M. Kratochvíl \& J. Jarošík. 2007. Impact of flood on distribution of bathypelagic perch fry layer along the longitudinal profile of large canyon-shaped reservoir. J. Fish Biol., 70: 11091119.

Conde-Porcuna, J. M, F. J. Valdéz, S. Romo \& C. Peréz-Martínez. 2011. Ephippial and subitaneous egg abortion: relevance for an obligate parthenogenetic Daphnia population. J. Limnol., 70: 69-75.

De Meester, L., A. Goméz, B. Okamura \& K. Schwenk. 2002. The Monopolization Hypothesis and the dispersal-gene flow paradox in aquatic organisms. Acta Oecol., 23: 121-135.

Edmondson, W.T. 1955. The seasonal life history of Daphnia in an arctic lake. Ecology, 36: 439-455.

Fryer, G. 1996. Diapause, a potent force in the evolution of freshwater crustaceans. Hydrobiologia, 320: 1-14.

Hairston Jr., N.G. 1996. Zooplankton egg banks as biotic reservoirs in changing environments. Limnol. Oceanogr., 41: 1087-1092.

Hejzlar, J. \& V. Vyhnálek. 1998. Longitudinal heterogeneity of phosphorus and phytoplankton concentrations in deepvalley reservoirs. Int. Rev. Hydrobiol., 83 (Special Issue): 139-146.

Hejzlar, J., J. Borovec, V. Perglová, E. Hanslík \& L. Nedvěd. 2008. Datování sedimentů ve vodárenské nádrži Římov pomocí cesia 137 [Dating of sediments in the drinking water reservoir Římov with caesium-137]. In: Hanslík, E., Radionuklidy a ionizující záření ve vodním hospodářství [Radionuclides and ionizing radiation in water management]. Proceeding of a conference held in České Budějovice on May 5-7, 2008. Česká vědeckotechnická vodohospodářská společnost, Praha: 59-64 (in Czech).

Hotový, J. \& A. Petrusek. 2007. Resting stage density and hatching of two cladoceran species from small ephemeral waters. Fund. Appl. Limnol., 169: 177-187.

Jezbera, J., J. Nedoma \& K. Šimek. 2003. Longitudinal changes in protistan bacterivory and bacterial production in two canyon-shaped reservoirs of different trophic status. Hydrobiologia, 504: 115-130.

Kearns, C.M., N.G. Hairston, Jr. \& D. H. Kesler. 1996. Particle transport by benthic invertebrates: its role in egg bank dynamics. Hydrobiologia, 332: 63-70.

Kerfoot, W.C., J.W. Budd, B.J. Eadie, H.A. Vanderploeg \& M. Agy. 2004. Winter storms: Sequential sediment traps record Daphnia ephippial production, resuspension, and sediment interactions. Limnol. Oceanogr., 49: 1365-1381.

Kubečka, J., M. Prchalová, L. Hladík, M. Vašek \& M. Říha. 2004. Vliv katastrofální povodně na složení rybí obsádky údolní nádrže Římov [Effect of catastrophic flooding on the composition of the fish stock of the Rímov reservoir]. In: Lusk, S., V. Lusková \& K. Halačka (Eds), Biodiverzita ichtyofauny Ceské republiky (V) [Biodiversity of fishes of the Czech Republic (V)]. Proceedings of the conference held in Brno on November 4, 2003. Ustav biologie obratlovců AV ČR a AOPK ČR Praha: 129-136 (in Czech with English abstract).

Lindholm, M. \& D. O. Hessen. 2007. Zooplankton succession on seasonal floodplains: surfing on a wave of food. Hydrobiologia, 592: 95-104. 
Matsuzaki, S.S., N. Usio, N. Takamura \& I. Washitani. 2007. Effects of common carp on nutrient dynamics and littoral community composition: roles of excretion and bioturbation. Fund. Appl. Limnol., 168: 27-38.

Paidere, J., D. Gruberts, A. Škute \& I. Druvietis. 2007. Impact of two different flood pulses on planktonic communities of the largest floodplain lakes of the Daugava River (Latvia). Hydrobiologia, 592: 303-314.

Petrusek, A., J. Seda, J. Macháček, Š. Ruthová \& P. Šmilauer. 2008a. Daphnia hybridization along ecological gradients in pelagic environments: the potential for the presence of hybrid zones in plankton. Philos. Trans. R. Soc. B, 363: 2931-2941.

Petrusek, A., A. Hobaek, J.P. Nilssen, M. Skage, M. Černý, N. Brede \& K. Schwenk. 2008b. A taxonomic reapprasial of the European Daphnia longispina complex (Crustacea, Cladocera, Anomopoda). Zool. Scr., 37: 507-519.

Prchalová, M., J. Kubečka, M. Vašek, J. Peterka, J. Seda, T. Jůza, M. Ríha, O. Jarolím, M. Tušer, M. Kratochvíl, M. Čech, V. Draštík, J. Frouzová \& E. Hohausová. 2008. Distribution patterns of fishes in a canyon-shaped reservoir. J. Fish Biol., 73: 54-78.

Rellstab, C., V. Maurer, M. Zeh, H.R. Bürgi \& P. Spaak. 2007. Temporary collapse of the Daphnia population in turbid and ultra-oligotrophic Lake Brienz. Aquat. Sci., 69: 257-270.

Richardson, W.B. 1992. Microcrustacea in flowing water experimental analysis of washout times and a field test. Freshwat. Biol., 28: 217-230.

Ř́ha, M., J. Kubečka, M. Vašek, J. Seda, T. Mrkvička, M. Prchalová, J. Matěna, M. Hladík, M. Čech, V. Draštík, J. Frouzová, E. Hohausová, O. Jarolím, T. Jůza, M. Kratochvíl, J. Peterka \& M. Tušer. 2009. Long-term development of fish populations in the Rímov Reservoir. Fisheries Manag. Ecol., 16: 121-129.

Ritvo, G., M. Kochba \& Y. Avnimelech. 2004. The effects of common carp bioturbation on fishpond bottom soil. Aquaculture, 242: 345-356.

Rossi, V., G. Rossetti, M. Benatti, P. Menozzi \& I. Ferrari. 1998. Ephippial eggs and dynamics of the clonal structure of Daphnia longispina (Crustacea: Cladocera) in a mountain lake (Lago Scuro Parmense, Northern Italy). Arch. Hydrobiol., 52: 195-206.

Rother, A., M. Pitsch \& S. Hülsmann. 2010. The importance of hatching from resting eggs for population dynamics and genetic composition of Daphnia in a deep reservoir. Freshwat. Biol., 55: 2319-2331.

Rychtecký, P. \& P. Znachor. 2011. Spatial heterogeneity and seasonal succession of phytoplankton along the longitudinal gradient in a eutrophic reservoir. Hydrobiologia, 663: 175-186.

Schwartz, S.S. \& P.D.N. Hebert. 1987. Methods for the activation of the resting eggs of Daphnia. Freshwat. Biol., 17: 373-379.
Seda, J. 1989. Main factors affecting spring development of herbivorous Cladocera in the Rímov Reservoir (Czechoslovakia). Arch. Hydrobiol. Beih. Ergebn. Limnol., 33: 619-630.

Seda, J. \& M. Devetter. 2000. Zooplankton community structure along a trophic gradient in a canyon-shaped dam reservoir. J. Plankton Res., 22: 1829-1840.

Seda, J. \& J. Macháček. 1998. The effect of flow-through regimes on zooplankton densities in a canyon-shaped dam reservoir. Int. Rev. Hydrobiol., 83: 477-484.

Seda, J., K. Kolářová, K., A. Petrusek \& J. Macháček. 2007a. Daphnia galeata in the deep hypolimnion: spatial differentiation of a "typical epilimnetic" species. Hydrobiologia, 594: 47-57.

Seda, J., A. Petrusek, J. Macháček \& P. Šmilauer. 2007b. Spatial distribution of the Daphnia longispina species complex and other planktonic crustaceans in the heterogeneous environment of canyon-shaped reservoirs. $J$. Plankton Res., 29: 619-628.

Šimek, K., K. Horňák, J. Jezbera, J. Nedoma, P. Znachor, J. Hejzlar \& J. Seda. 2008. Spatio-temporal patterns of bacterioplankton production and community composition related to phytoplankton composition and protistan bacterivory in a dam reservoir. Aquat. Microb. Ecol., 51: 249262.

Straškraba, M. 1998. Limnological differences between deep valley reservoirs and deep lakes. Int. Rev. Hydrobiol., 83: $1-12$.

Vaníčková, I., J. Seda \& A. Petrusek. 2010. The stabilizing effect of resting egg banks of the Daphnia longispina species complex for longitudinal taxon heterogeneity in long and narrow reservoirs. Hydrobiologia, 643: 85-95.

Vanoverbeke, J. \& L. De Meester. 2010. Clonal erosion and genetic drift in cyclical parthenogens - the interplay between neutral and selective processes. J. Evol. Biol., 23: 997-1012.

Vašek, M., J. Kubečka, J. Peterka, M. Čech, V. Draštík, M. Hladík, M. Prchalová \& J. Frouzová. 2004. Longitudinal and vertical spatial gradients in the distribution of fish within a canyon-shaped reservoir. Int. Rev. Hydrobiol., 89: 352-362.

Zaffagnini, F. 1987. Reproduction in Daphnia. In: Peters, R.H. \& R. de Bernardi (Eds), Daphnia. Mem. Ist. ital. Idrobiol., 45: 245-284.

Znachor, P., E. Zapomělová, K. Řeháková, J. Nedoma \& K. Śimek. 2008. The effect of extreme rainfall on summer succession and vertical distribution of phytoplankton in a lacustrine part of a eutrophic reservoir. Aquat. Sci., 70: 7786.

Zurek, R. \& E. Dumnicka. 1989. The fate of zooplankton in a river after leaving a dam reservoir. Arch. Hydrobiol. Beih. Ergebn. Limnol., 33: 549-561. 